\title{
War in Iraq: A Timeline
}

1963: Arab Socialist Baath Party rises to power

1979: $\quad$ Saddam Hussein becomes president

1980-1988: Saddam Hussein initiates Iran-Iraq War, which kills more than 1 million and is the longest conventional war between two countries in the twentieth century

1988: Iraqi military attacks northern Kurdish town of Halabjah with poison gas, killing thousands

1990: Saddam Hussein invades Kuwait on August 2

1990-2003: Iraq is economically sanctioned over thirteen years by the UN Security Council for its aggression on its neighbors; all imports are restricted, except for vital medicines

1991: US and coalition of thirty nations invade Iraq in January, in the First Gulf War that leads to Saddam's surrender after six weeks

1991: Following Saddam's defeat, southern Iraqi Shia and northern Iraqi Kurds stage an intifada (uprising) against Saddam, supported by the US military; however, Saddam retaliates with a brutal crackdown, in which Shia and Kurdish populations are forced to flee

1991-1997: Southern Iraqis spend time in Saudi Arabian desert refugee camps, before being granted refugee admission to the United States; many end up in Arab Detroit 
1995: Oil-for-Food Programme initiated by the United Nations to alleviate major sanction-induced food and medicine shortages; United Nations allows partial resumption of Iraq's oil exports

2003: United States declares war on Iraq on March 19, based on intelligence reports that Saddam Hussein possesses "weapons of mass destruction" (WMDs)

2003-2011: The Second Gulf War, also known as "Operation Iraqi Freedom" (OIF), is initiated, lasting nearly nine years and setting off years of violent conflict between sectarian and jihadist groups competing for power

2006: Saddam Hussein is executed for crimes against humanity

2007: $\quad$ President George W. Bush announces deployment of 30,000 more US troops, in Iraq "surge" to provide better security and to reduce casualties; Britain hands over its control of southern Iraq to Iraqi forces after five years

2007-2015: Second major wave of Iraqi refugee resettlement in the United States; 125,000 of 200,000 Iraqi refugees enter the United States

2009: Al-Quaeda-linked Islamic State of Iraq emerges, claiming responsibility for suicide bombings in Baghdad

2011: United States completes troop withdrawal on December 18, marking official end to US-led war in Iraq

2013: Islamic State of Iraq and Syria (ISIS) emerges as an independent Sunni jihadist group, declaring itself an "Islamic state"; reports being to emerge of a full-blown sectarian war in Iraq

2014: $\quad$ ISIS seizes Mosul, Iraq's second largest city

2015: Iraqi Army launches offensive against ISIS to take back key Sunni-dominant cities such as Tikrit, Ramadi, and Fallujah

2016: Iraqi government forces wage war against ISIS in city of Mosul, with US military support 